\title{
Assessment of the Antioxidant and Reactive Oxygen Species Scavenging Activity of Methanolic Extract of Caesalpinia crista Leaf
}

\author{
Sourav Mandal, Bibhabasu Hazra, Rhitajit Sarkar, Santanu Biswas, \\ and Nripendranath Mandal
}

Division of Molecular Medicine, Bose Institute, P-1/12 CIT Scheme VIIM, Kolkata-700054, India

Correspondence should be addressed to Nripendranath Mandal, mandaln@rediffmail.com

Received 26 December 2008; Accepted 28 May 2009

Copyright (c) 2011 Sourav Mandal et al. This is an open access article distributed under the Creative Commons Attribution License, which permits unrestricted use, distribution, and reproduction in any medium, provided the original work is properly cited.

\begin{abstract}
"Oxidative stress" is initiated by reactive oxygen species (ROS), which are responsible for majority of the diseases. However, antioxidants with ROS scavenging ability may have great relevance in the prevention of oxidative stress. The present study was undertaken, using a 70\% methanolic extract of Caesalpinia crista leaves, to examine different in vitro tests in diversified fields including total antioxidant activity, scavenging activities for various ROS, iron chelating activity and phenolic and flavonoid contents. Total antioxidant activity was evaluated as trolox equivalent antioxidant capacity value of $0.546 \pm 0.014$. The extract was investigated for different ROS scavenging activities and $\mathrm{IC}_{50}$ values were found to be $0.44 \pm 0.1 \mathrm{mg} / \mathrm{ml}, 24.9 \pm 0.98 \mu \mathrm{g} / \mathrm{ml}, 33.72 \pm$ $0.85 \mu \mathrm{g} / \mathrm{ml}, 61.13 \pm 3.24 \mu \mathrm{g} / \mathrm{mL}$ and $170.51 \pm 4.68 \mu \mathrm{g} / \mathrm{mL}$ for hydroxyl, superoxide, nitric oxide, singlet oxygen and hypochlorous acid, respectively; however, no significant results were obtained in scavenging of hydrogen peroxide and peroxynitrite anion. The extract was found to be a potent iron chelator with $\mathrm{IC}_{50}=279.85 \pm 4.72 \mu \mathrm{g} / \mathrm{mL}$. The plant extract $(100 \mathrm{mg})$ yielded $50.23 \pm$ $0.003 \mathrm{mg} / \mathrm{mL}$ gallic acid equivalent phenolic content and $106.83 \pm 0.0003 \mathrm{mg} / \mathrm{mL}$ quercetin equivalent flavonoid content. In the in vivo experiments, the extract treatment showed significant increase in the level of superoxide dismutase, catalase, glutathione$S$-transferase and reduced glutathione. In a word, it may be concluded that $70 \%$ methanol extract of $C$. crista leaves acts as an antioxidant and ROS scavenger; which may be due to the presence of phenolic and flavonoid compounds.
\end{abstract}

\section{Introduction}

Reactive oxygen species (ROS), generated in cells, are fundamental in modulating various physiological functions and represent an essential part of aerobic life and metabolism [1]. Sometimes, excessive generation of these radicals disrupts the antioxidant defense system of the body which may lead to "oxidative stress". This situation brings about a variety of disorders including coronary heart disease, neurodegenerative disorders, diabetes, arthritis, inflammation, lung damage and cancer $[2,3]$. Since, antioxidants are capable of preventing oxidative damage, the wide use of natural antioxidants as a replacement of conventional synthetic antioxidants in food and food supplements has been employed owing to the fact that natural products are considered to be promising and safe source.

Caesalpinia crista Linn. (syn. C. bonducella [L.] Roxb.) (family-Fabaceae) is a popular medicinal plant widely distributed throughout the tropical and subtropical regions of Southeast Asia. It is found throughout the hot and humid part of India, Myanmar and Sri Lanka. In India, it is known as Katikaranja and is distributed in West Bengal, Kerala and Maharashtra. It is a large straggling and very thorny shrub. Medicinally, most widely used part is seed kernel which is reported as a rich source of cassane- and norcassane-type diterpenoids [4]. Some new diterpenoids are also isolated from stems and root of this plant [5]. The plant is locally known as Ka-Lain in Myanmar and its seeds are used as anthelmintic, antipyretic, anti-inflammatory and antimalarial agent. In Indonesia, it is known as Bagor and decoction of root have been used as a tonic for the treatment of rheumatism. Traditionally, in Ayurveda, this plant was used for the treatment of gynecological disorders, skin diseases, constipation, piles and ulcers [6]. It is also reported to have antidiuretic, antibacterial, antianaphylactic, antidiarrhoeal, antiameobic and antiviral $[7,8]$ properties. 
It also possesses antidiabetic and hypoglycaemic activity [9].

It has been reported that the methanol extract of $C$. crista seed and seed kernel possess antifeedant [10] and anthelmintic [11] property. There is still no report on the antioxidant property of this plant leaf. The present study is aimed to evaluate the antioxidant potential and ROS scavenging activity from the $70 \%$ methanol extract of $C$. crista leaf.

\section{Methods}

2.1. Chemicals. 2,2'-Azinobis-(3-ethylbenzothiazoline-6-sulfonic acid) (ABTS) was obtained from Roche Diagnostics, Mannheim, Germany. 6-Hydroxy-2,5,7,8-tetramethylchroman-2-carboxylic acid (Trolox) was obtained from Fluka, Buchs, Switzerland. 2-Deoxy-2-ribose, trichloroacetic acid (TCA), mannitol, nitro blue tetrazolium (NBT), reduced nicotinamide adenine dinucleotide phosphate (NADH), phenazine methosulfate (PMS), sodium nitroprusside (SNP), sulfanilamide, naphthylethylenediamine dihydrochloride (NED), L-histidine, lipoic acid, sodium pyruvate, quercetin, glutathione reduced, 5,5'-dithiobis-2-nitrobenzoic acid (DTNB), 1-chloro-2,4-dinitrobenzene (CDNB) and ferrozine were obtained from Sisco Research Laboratories Pvt. Ltd, Mumbai, India. Potassium hexacyanoferrate, FolinCiocalteu reagent, butylated hydroxy toluene (BHT), sodium hypochlorite $(\mathrm{NaOCl})$, aluminum chloride $\left(\mathrm{AlCl}_{3}\right)$, xylenol orange and $\mathrm{N}, \mathrm{N}$-dimethyl-4-nitrosoaniline were obtained from Merck, Mumbai, India. Gallic acid and curcumin were obtained from MP Biomedicals, France. HEPES buffer and catalase were obtained from HiMedia Laboratories Pvt. Ltd, Mumbai, India. Evans Blue was purchased from BDH, England. Diethylene-triamine-pentaacetic acid (DTPA) was obtained from Spectrochem Pvt. Ltd, Mumbai, India. Thiobarbituric acid (TBA) was obtained from Loba Chemie, Mumbai, India.

2.2. Plant Material. The leaves of C. crista were collected from the Bankura district of West Bengal, India. It was identified and authenticated through the Central Research Institute (Ayurveda), Kolkata, India and a voucher specimen (CRHS 121/08) was submitted there.

2.3. Animals. Male Swiss albino mice $(20 \pm 2 \mathrm{~g})$ were purchased from Chittaranjan National Cancer Institute (CNCI), Kolkata, India and were maintained under a constant 12h dark/light cycle at an environmental temperature of 22 $\pm 2^{\circ} \mathrm{C}$. The animals were provided with normal laboratory pellet diet and water ad libitum. All experiments were performed after obtaining approval from the institutional animal ethics committee.

2.4. Sample Preparation. The powder $(100 \mathrm{~g})$ of the dried leaves of $C$. crista was stirred using a magnetic stirrer with 500-mL mixture of methanol: water $(7: 3)$ for $15 \mathrm{~h}$; then the mixture was centrifuged at $2850 \mathrm{~g}$ and the supernatant decanted. The process was repeated again with the precipitated pellet. The supernatants were collected, concentrated in a rotary evaporator and lyophilized. The dried extract was stored at $-20^{\circ} \mathrm{C}$ until use.

\subsection{In Vitro Antioxidant Assay}

2.5.1. Trolox Equivalent Antioxidant Capacity (TEAC). Antioxidant activity of the extract was assayed depending on the ability of the sample to scavenge $\mathrm{ABTS}^{\bullet+}$ radical cation compared to trolox standard [12]. The $\mathrm{ABTS}^{\bullet+}$ radical cation was pregenerated by mixing $7-\mathrm{mM}$ ABTS stock solution with $2.45-\mathrm{mM}$ potassium persulfate (final concentration) and incubated for $12-16 \mathrm{~h}$ in dark at room temperature until the reaction was completed and absorbance was stable. The absorbance of $\mathrm{ABTS}^{\bullet+}$ was equilibrated to $0.70( \pm 0.02)$ by diluting with water at room temperature. Then $10 \mu \mathrm{L}$ $(0.05-10 \mathrm{mg} / \mathrm{mL})$ sample solution was mixed with $1-\mathrm{mL}$ $\mathrm{ABTS}^{\bullet+}$ solution and after $6 \mathrm{~min}$, absorbance was measured at $734 \mathrm{~nm}$. All experiments were repeated six times. The percentage inhibition of absorbance was calculated and plotted as a function of the concentration of standard and sample to determine the TEAC. TEAC was calculated from dividing the gradient of the plot for the sample by the gradient of the plot for trolox.

2.5.2. Hydroxyl Radical Scavenging Activity. This assay was performed by a standard method [13] with a slight modification. Hydroxyl radical was generated by the $\mathrm{Fe}^{3+}$-ascorbateEDTA- $\mathrm{H}_{2} \mathrm{O}_{2}$ system (Fenton reaction). The assay is based on the quantification of the 2-deoxyribose degradation product, by its condensation with TBA. The reaction mixture contained, in a final volume of $1 \mathrm{~mL}, 2$-deoxy-2-ribose (2.8 mM); $\mathrm{KH}_{2} \mathrm{PO} 4-\mathrm{KOH}$ buffer $(20 \mathrm{mM}, \mathrm{pH} 7.4) ; \mathrm{FeCl}_{3}$ $(100 \mu \mathrm{M})$; EDTA $(100 \mu \mathrm{M}) ; \mathrm{H}_{2} \mathrm{O}_{2}(1.0 \mathrm{mM})$; ascorbic acid $(100 \mu \mathrm{M})$ and various concentrations $(0-1 \mathrm{mg} / \mathrm{mL})$ of test sample or reference compound. After incubation at $37^{\circ} \mathrm{C}$ for $1 \mathrm{~h}, 1 \mathrm{~mL} 2.8 \%$ TCA was added to $0.5 \mathrm{~mL}$ of the reaction mixture. Then 1-mL 1\% aqueous TBA was added to the solution and incubated at $90^{\circ} \mathrm{C}$ for $15 \mathrm{~min}$ to develop the color. After cooling, the absorbance was measured at $532 \mathrm{~nm}$ against the blank solution. All tests were performed six times. Mannitol, a classical ${ }^{\bullet} \mathrm{OH}$ scavenger, was used as a positive control. Percentage inhibition was evaluated by comparing the results of the test and blank solution.

2.5.3. Scavenging of Superoxide Radicals. This activity was done based on the reduction of NBT according to a previously reported method [14]. The non-enzymatic phenazine methosulfate-nicotinamide adenine dinucleotide (PMS/NADH) system generates superoxide radicals that reduce nitro blue tetrazolium (NBT) into a purple-colored formazan. The $1-\mathrm{mL}$ reaction mixture contained phosphate buffer (20 mM, pH 7.4), NADH (73 $\mu \mathrm{M})$, NBT (50 $\mu \mathrm{M})$, PMS $(15 \mu \mathrm{M})$ and various concentrations $(0-50 \mu \mathrm{g} / \mathrm{mL})$ of sample solution. After incubation for $5 \mathrm{~min}$ at ambient temperature, the absorbance was taken at $562 \mathrm{~nm}$ against an appropriate blank solution. All tests were performed six times. Quercetin was used as positive control. 
2.5.4. Assay of Nitric Oxide Radical Scavenging. At physiological $\mathrm{pH}$, nitric oxide generated from aqueous sodium nitroprusside (SNP) solution interacts with oxygen to produce nitrite ions which were measured by Griess Illosvoy reaction [15]. The 3-mL reaction mixture contained 10 $\mathrm{mM}$ SNP, phosphate buffered saline $(\mathrm{pH}$ 7.4) and various doses $(0-120 \mu \mathrm{g} / \mathrm{mL})$ of test solution. After incubation for $150 \mathrm{~min}$ at $25^{\circ} \mathrm{C}, 1-\mathrm{mL}$ sulfanilamide $(0.33 \%$ in $20 \%$ glacial acetic acid) was added to $0.5 \mathrm{~mL}$ of the incubated solution and allowed to stand for $5 \mathrm{~min}$. Then $1 \mathrm{~mL}$ of napthylethylenediamine dihydrochloride (NED) $(0.1 \% \mathrm{w} / \mathrm{v})$ was added and the mixture was incubated for $30 \mathrm{~min}$ at $25^{\circ} \mathrm{C}$. The pink chromophore formed during diazotization of nitrite ions with sulphanilamide and subsequent coupling with NED was measured spectrophotometrically at $540 \mathrm{~nm}$ against blank sample. All tests were performed six times. Curcumin was used as a standard.

2.5.5. Scavenging Activity of Hydrogen Peroxide. This activity was determined according to a method [16] with minor changes. Aliquot of $50-\mathrm{mM} \mathrm{H}_{2} \mathrm{O}_{2}$ and various concentrations $(0-2.0 \mathrm{mg} / \mathrm{mL})$ of samples were mixed $(1: 1 \mathrm{v} / \mathrm{v})$ and incubated for $30 \mathrm{~min}$ at room temperature. After incubation, $90 \mu \mathrm{l}$ of the $\mathrm{H}_{2} \mathrm{O}_{2}$-sample solution was mixed with $10 \mu \mathrm{l}$ HPLC-grade methanol and 0.9-mL FOX reagent was added (previously prepared by mixing 9 volumes of $4.4-\mathrm{mM}$ BHT in HPLC-grade methanol with 1 volume of $1-\mathrm{mM}$ xylenol orange and 2.56- $\mathrm{mM}$ ammonium ferrous sulfate in 0.25 $\mathrm{M} \mathrm{H}_{2} \mathrm{SO}_{4}$ ). The reaction mixture was then vortexed and incubated at room temperature for $30 \mathrm{~min}$. The absorbance of ferric-xylenol orange complex was measured at $560 \mathrm{~nm}$. All tests were carried out six times and sodium pyruvate was used as the reference compound.

2.5.6. Determination of the Effects on Peroxynitrite. Peroxynitrite $\left(\mathrm{ONOO}^{-}\right)$was synthsized following a method by Beckman et al. [17]. An acidic solution (0.6- $\mathrm{M} \mathrm{HCl)} \mathrm{of} \mathrm{5-}$ $\mathrm{mL} \mathrm{H}_{2} \mathrm{O}_{2}(0.7 \mathrm{M})$ was mixed with $5-\mathrm{mL} 0.6 \mathrm{M} \mathrm{KNO}_{2}$ on an ice bath for $1 \mathrm{~s}$ and $5-\mathrm{mL}$ ice-cold $1.2-\mathrm{M} \mathrm{NaOH}$ was added to the reaction mixture. Excess $\mathrm{H}_{2} \mathrm{O}_{2}$ was removed by treatment with granular $\mathrm{MnO}_{2}$ prewashed with $1.2-\mathrm{M} \mathrm{NaOH}$ and the reaction mixture was left overnight at $-20^{\circ} \mathrm{C}$. Peroxynitrite solution was collected from the top of the frozen mixture and the concentration was measured spectrophotometrically at $302 \mathrm{~nm}(\varepsilon=1670 / \mathrm{M} \mathrm{cm})$.

The Evans Blue bleaching assay [18] was used to measure the peroxynitrite scavenging activity, with slight modification. The reaction mixture contained $50-\mathrm{mM}$ phosphate buffer ( $\mathrm{pH}$ 7.4), 0.1-mM DTPA, $90-\mathrm{mM} \mathrm{NaCl}, 5-\mathrm{mM} \mathrm{KCl}$, $12.5 \mu \mathrm{M}$ Evans Blue, various doses of plant extract $(0$ $200 \mu \mathrm{g} / \mathrm{mL}$ ) and $1-\mathrm{mM}$ peroxynitrite in a final volume of $1 \mathrm{~mL}$. After incubation at $25^{\circ} \mathrm{C}$ for $30 \mathrm{~min}$ the absorbance was measured at $611 \mathrm{~nm}$. The percentage of scavenging of $\mathrm{ONOO}^{-}$was calculated by comparing the results of the test and blank sample. All tests were performed six times. Gallic acid was used as reference compound.
2.5.7. Reaction with Singlet Oxygen. The production of singlet oxygen $\left({ }^{1} \mathrm{O}_{2}\right)$ was determined by monitoring $\mathrm{N}, \mathrm{N}$ dimethyl-4-nitrosoaniline ( $\mathrm{RNO}$ ) bleaching, using a previously reported spectrophotometric method [19]. Singlet oxygen was generated by a reaction between $\mathrm{NaOCl}$ and $\mathrm{H}_{2} \mathrm{O}_{2}$ and the bleaching of RNO was read at $440 \mathrm{~nm}$. The reaction mixture contained $45-\mathrm{mM}$ phosphate buffer $(\mathrm{pH}$ 7.1), 50-mM NaOCl, 50-mM $\mathrm{H}_{2} \mathrm{O}_{2}, 50-\mathrm{mM}$ L-histidine, $10 \mu \mathrm{M}$ RNO and various concentrations $(0-100 \mu \mathrm{g} / \mathrm{mL})$ of sample in a final volume $2 \mathrm{~mL}$. It was incubated at $30^{\circ} \mathrm{C}$ for $40 \mathrm{~min}$ and decrease in the absorbance of $\mathrm{RNO}$ was measured at $440 \mathrm{~nm}$. The scavenging activity of sample was compared with that of lipoic acid, used as a reference compound. All tests were performed six times.

2.5.8. Reaction with Hypochlorous Acid. Hypochlorous acid $(\mathrm{HOCl})$ was prepared just before the experiment by adjusting the $\mathrm{pH}$ of a $10 \%(\mathrm{v} / \mathrm{v})$ solution of $\mathrm{NaOCl}$ to 6.2 with $0.6 \mathrm{M}$ $\mathrm{H}_{2} \mathrm{SO}_{4}$ and the concentration of $\mathrm{HOCl}$ was determined by using the absorbance at $235 \mathrm{~nm}$ and the molar extinction coefficient of $100 / \mathrm{M} \mathrm{cm}$.

The assay was carried out as described by Aruoma and Halliwell [20] with minor changes. The scavenging activity was evaluated by measuring the decrease in absorbance of catalase at $404 \mathrm{~nm}$. The reaction mixture contained, in a final volume of $1 \mathrm{~mL}, 50-\mathrm{mM}$ phosphate buffer ( $\mathrm{pH} 6.8$ ), catalase $(7.2 \mu \mathrm{M}), \mathrm{HOCI}(8.4 \mathrm{mM})$ and increasing concentrations $(0-$ $200 \mu \mathrm{g} / \mathrm{mL}$ ) of plant extract. The assay mixture was incubated at $25^{\circ} \mathrm{C}$ for $20 \mathrm{~min}$ and the absorbance was taken against an appropriate blank. All tests were performed six times. Ascorbic acid was used as the reference compound.

2.5.9. $\mathrm{Fe}^{2+}$ Chelation. The chelating activity of the extracts for ferrous ion was evaluated by a standard method [21] with minor changes. The reaction was carried out in HEPES buffer $(20 \mathrm{mM}, \mathrm{pH}$ 7.2). Briefly, various concentrations of plant extracts $(0-300 \mu \mathrm{g} / \mathrm{mL})$ were added to $12.5 \mu \mathrm{M}$ ferrous sulfate solution and the reaction was initiated by the addition of ferrozine $(75 \mu \mathrm{M})$. The mixture was shaken vigorously and incubated for $20 \mathrm{~min}$ at room temperature, and the absorbance was measured at $562 \mathrm{~nm}$. All tests were performed for six times. EDTA was used as a positive control.

2.5.10. Measurement of Reducing Power. The $\mathrm{Fe}^{3+}$ reducing power of the extract was determined by the method of Oyaizu [22] with a slight modification. Different concentrations $(0-1.0 \mathrm{mg} / \mathrm{mL})$ of extract $(0.5 \mathrm{~mL})$ were mixed with $0.5-\mathrm{mL}$ sphate buffer $(\mathrm{pH}$ 6.6) and $0.5-\mathrm{mL} 0.1 \%$ potassium hexacyanoferrate, followed by incubation at $50^{\circ} \mathrm{C}$ in water bath for $20 \mathrm{~min}$. After incubation, $0.5-\mathrm{mL} \mathrm{10 \%} \mathrm{TCA}$ was added to terminate the reaction. The upper portion of the solution $(1 \mathrm{~mL})$ was mixed with $1 \mathrm{~mL}$ of distilled water and $0.1-\mathrm{mL} 0.01 \% \mathrm{FeCl}_{3}$ solution was added. The reaction mixture was left for $10 \mathrm{~min}$ at room temperature and the absorbance was measured at $700 \mathrm{~nm}$ against appropriate blank solution. All tests were performed six times. A higher absorbance of the reaction mixture indicated greater reducing power. Ascorbic acid was used as a positive control. 
2.5.11. Determination of Total Phenolic Content. Total phenolic content was determined using Folin-Ciocalteu (FC) reagent according to the method of Singleton and Rossi [23] with a slight modification. Briefly, $0.1 \mathrm{~mL}$ of extract was mixed with $0.75 \mathrm{~mL}$ of FC reagent (previously diluted 1000fold with distilled water) and incubated for $5 \mathrm{~min}$ at $22^{\circ} \mathrm{C}$; then $0.06 \% \mathrm{Na}_{2} \mathrm{CO}_{3}$ solution was added to the mixture. After incubation at $22^{\circ} \mathrm{C}$ for $90 \mathrm{~min}$, the absorbance was measured at $725 \mathrm{~nm}$. The phenolic content was evaluated from a gallic acid standard curve.

2.5.12. Determination of Total Flavonoids. Total flavonoid content was decided according to a known method [24] using quercetin as a standard. The plant extract of $0.1 \mathrm{~mL}$ was added to $0.3-\mathrm{mL}$ distilled water followed by 0.03 $\mathrm{mL} 5 \% \mathrm{NaNO}_{2}$. After $5 \mathrm{~min}$ at $25^{\circ} \mathrm{C}, 0.03-\mathrm{mL} 10 \% \mathrm{AlCl}_{3}$ was added. After another $5 \mathrm{~min}$, the reaction mixture was treated with $0.2-\mathrm{mL} 1-\mathrm{mM} \mathrm{NaOH}$. Finally the reaction mixture was diluted to volume $(1 \mathrm{~mL})$ with water. Then the absorbance was measured at $510 \mathrm{~nm}$. The flavonoid content was calculated from a quercetin standard curve.

\subsection{In Vivo Antioxidant Assay}

2.6.1. Experimental Design. Animals were divided into four groups containing six animals in each group. Group I animals served as control and received normal saline only. Groups II, III and IV received the plant extract at a dose of 10, 50 and $100 \mathrm{mg} / \mathrm{kg}$ body weight, respectively. The treatments were carried out orally for 7 days and on the 8th day all the animals were sacrificed by cervical dislocation. The liver was rapidly removed and after washing with ice-cold saline it was homogenized in 10 volume of $0.1-\mathrm{M}$ phosphate buffer ( $\mathrm{pH} 7.4$ ) containing 5-mM EDTA and 0.15-M NaCl, and centrifuged at $8000 \mathrm{~g}$ for $30 \mathrm{~min}$ at $4^{\circ} \mathrm{C}$. The supernatant was collected and used for the assay of enzyme activities. Protein concentration was estimated according to Lowry method [25] using BSA as standard.

2.6.2. Assay of Antioxidant Enzymes. Superoxide dismutase (SOD) was assayed by measuring the inhibition of the formation of blue colored formazan at $560 \mathrm{~nm}$ according to the technique of Kakkar et al. [26]. Catalase (CAT) activity was measured by following the decrease in $\mathrm{H}_{2} \mathrm{O}_{2}$ concentration spectrophotometrically over time at $240 \mathrm{~nm}$ according to a previously described method [27]. Glutathione-S-transferase (GST) was determined by the method of Hobig et al. [28] based on the formation of GSH-CDNB conjugate and increase in the absorbance at $340 \mathrm{~nm}$. Reduced glutathione (GSH) level was measured spectrophotometrically at $412 \mathrm{~nm}$ by the method of Ellman [29].

2.7. Statistical Analysis. All data are reported as the mean \pm SD of six measurements. Statistical analysis was performed using KyPlot version 2.0 beta 15 (32 bit). The $\mathrm{IC}_{50}$ values were calculated using the formula $Y=100 \times \mathrm{A} 1 /(X+\mathrm{A} 1)$ where $\mathrm{A} 1=\mathrm{IC}_{50}, Y=$ response $(Y=100 \%$ when $X=0), X$ $=$ inhibitory concentration. The $\mathrm{IC}_{50}$ values were compared

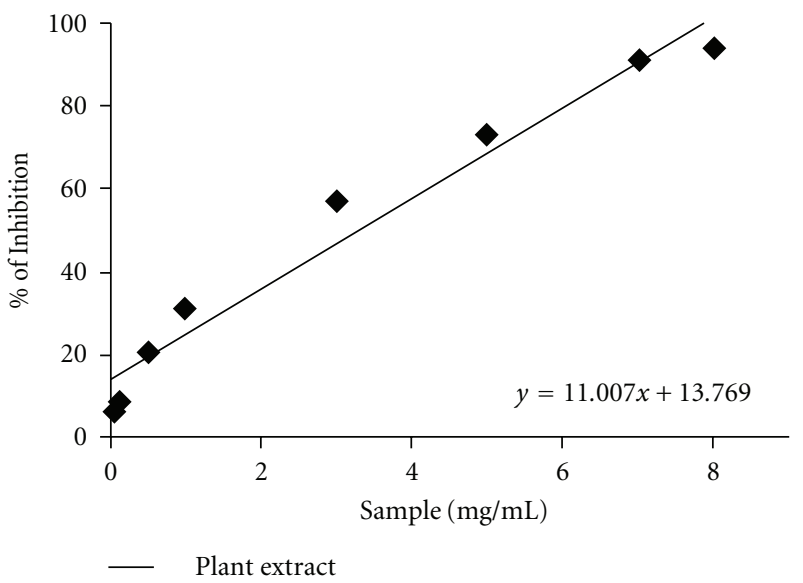

(a)

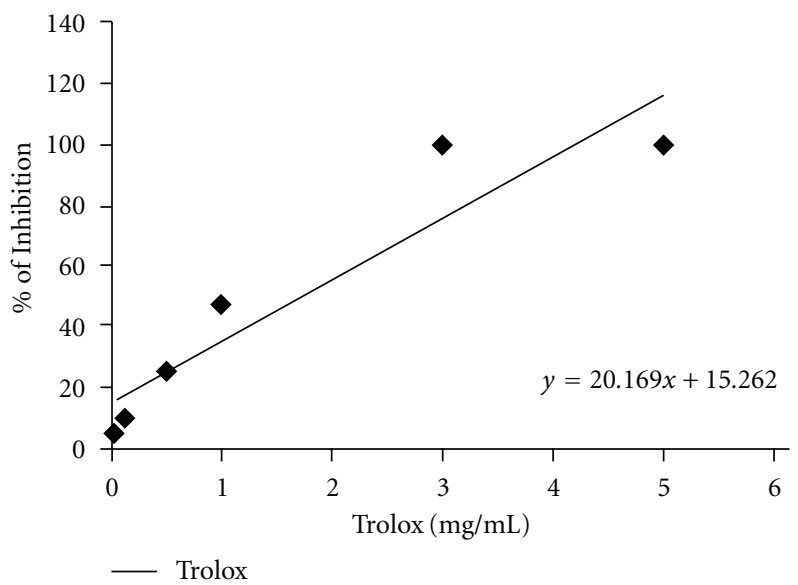

(b)

FIgUre 1: Total antioxidant activity. Effects of (a) C. crista leaf extract and (b) reference compound trolox on ABTS radical cation decolorization assay. The percentage of inhibition is plotted against concentration of sample. The value represented as mean \pm SD $(n=6)$.

by paired $t$-test. The results with a value of $P<.05$ were considered significant.

\section{Results}

\subsection{In Vitro Antioxidant Assay}

3.1.1. Total Antioxidant Activity. The total antioxidant activity of $C$. crista extract was calculated from the decolorization of the $\operatorname{ABTS}^{\bullet}{ }^{+}$, which was measured spectrophotometrically at $734 \mathrm{~nm}$. The percentage inhibition of absorbance was calculated and plotted as a function of concentration of the extract and of standard trolox, as shown in Figures 1(a) and $1(\mathrm{~b})$, respectively. The TEAC value of the extract was found to be $0.546 \pm 0.014$.

3.1.2. Inhibition of $\bullet \mathrm{OH}$-Induced Deoxyribose Degradation. The ability of the extract and standard mannitol to inhibit 


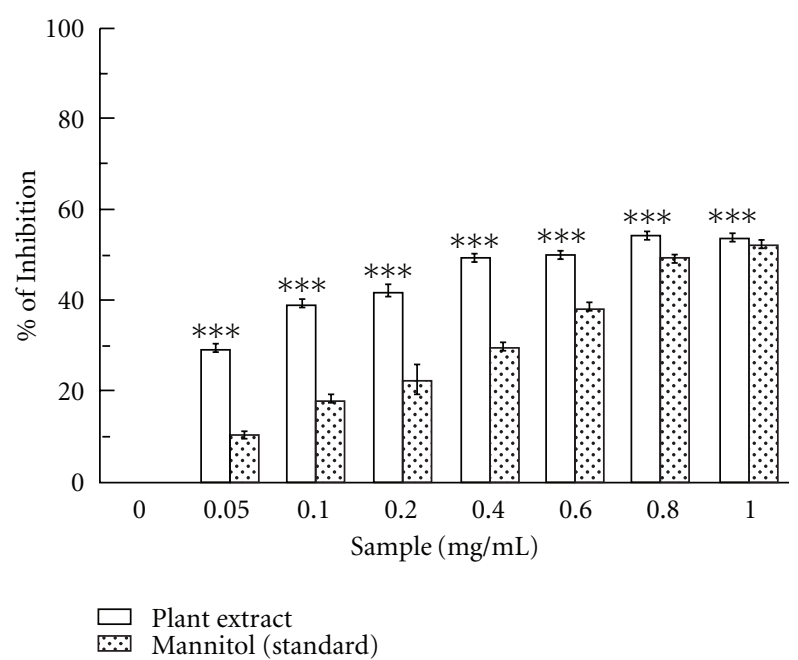

FIGURE 2: Inhibition of deoxyribose degradation. Hydroxyl radical scavenging activities of the C. crista leaf extract and the reference compound mannitol. The data represent the percentage of inhibition of deoxyribose degradation. ${ }^{* * *} P<.001$ versus $0 \mathrm{mg} / \mathrm{mL}$.

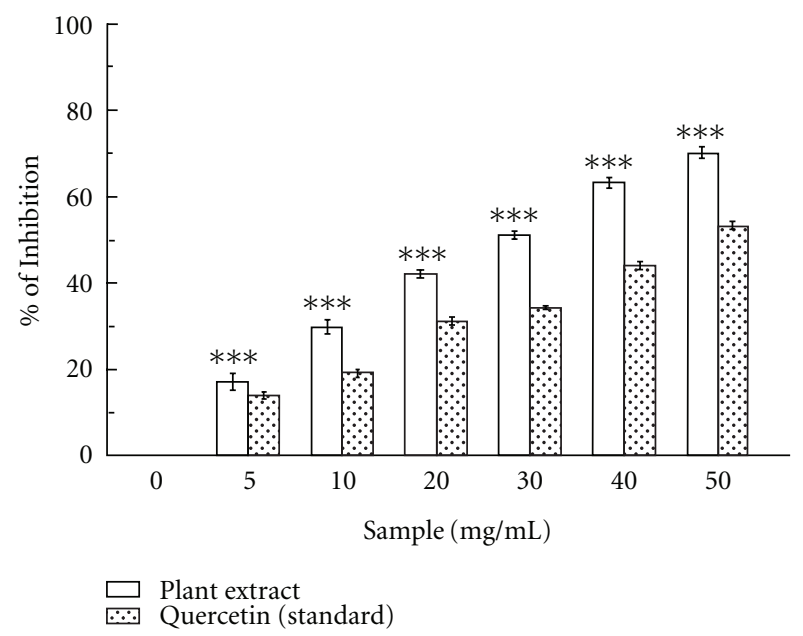

FIGURE 3: Superoxide radical scavenging activity. Scavenging effects of C. crista leaf extract and the standard quercetin on superoxide radical. The data represent the percentage of superoxide radical inhibition. ${ }^{* * *} P<.001$ versus $0 \mu \mathrm{g} / \mathrm{mL}$.

hydroxyl radical mediated deoxyribose degradation in $\mathrm{Fe}^{3+}$ EDTA-ascorbic acid and $\mathrm{H}_{2} \mathrm{O}_{2}$ reaction mixture was shown in this assay. The results have been shown in Figure 2. The $\mathrm{IC}_{50}$ value (Table 1 ) of extract and standard in hydroxyl radical scavenging assay was $0.44 \pm 0.1 \mathrm{mg} / \mathrm{mL}$ and $0.85 \pm$ $0.02 \mathrm{mg} / \mathrm{mL}$, respectively. At the concentration of $1 \mathrm{mg} / \mathrm{mL}$, the percentage inhibition was 53.75 and $52.05 \%$ for C. crista and mannitol, respectively.

3.1.3. Potent Superoxide Scavenger C. crista. PMS-NADH coupling yields superoxide radicals that can be measured by their ability to reduce NBT. The abilities of the plant extract and the reference compound quercetin to quench superoxide radicals from reaction mixture is reflected in

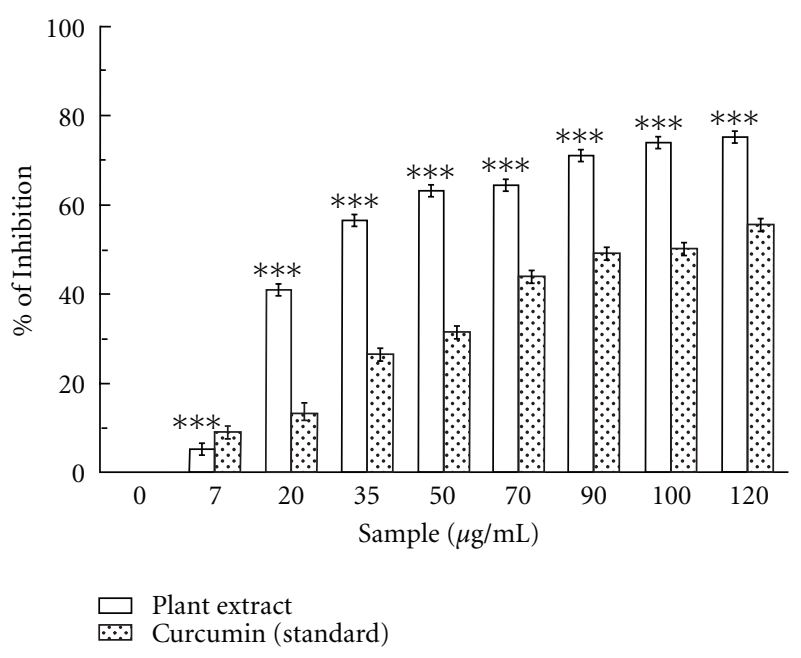

FIGURE 4: Nitric oxide radical scavenging activity. Nitric oxide radical scavenging activities of $C$. crista leaf extract and standard curcumin. The data represent the precentage of nitric oxide inhibition. ${ }^{* * *} P<0.001$ versus $0 \mu \mathrm{g} / \mathrm{mL}$.

the decrease of the absorbance at $560 \mathrm{~nm}$. As shown in Figure 3 , the $\mathrm{IC}_{50}$ values (Table 1 ) of plant extract and quercetin on superoxide scavenging activity were found to be $24.9 \pm 0.98 \mu \mathrm{g} / \mathrm{mL}$ and $47.38 \pm 0.68 \mu \mathrm{g} / \mathrm{mL}$, respectively. At $50 \mu \mathrm{g} / \mathrm{mL}$, the percentage inhibition of the plant extract was $70.23 \%$, whereas that of quercetin was $53.4 \%$.

3.1.4. Nitric Oxide Radical Scavenging Ability. Caesalpinia crista extract also superbly inhibits nitric oxide in dose dependent manner (Figure 4) with the $\mathrm{IC}_{50}$ (Table 1) value being $33.72 \pm 0.85 \mu \mathrm{g} / \mathrm{mL}$. Curcumin was used as a reference compound and $97.12 \pm 3.09 \mu \mathrm{g} / \mathrm{mL}$ curcumin was needed for $50 \%$ inhibition. The $\mathrm{IC}_{50}$ value of the extract was lesser than that of the standard. At $120 \mu \mathrm{g} / \mathrm{mL}$, the percentage inhibition of the plant extract was $75.26 \%$, whereas that of curcumin was $55.68 \%$.

3.1.5. Hydrogen Peroxide Scavenging. The scavenging activity for hydrogen peroxide of C. crista was not at all worth acknowledgeable in the assay performed by the FOX reagent method. The $\mathrm{IC}_{50}$ value for the plant extract was found to be indeterminable, whereas that of the standard sodium pyruvate was $3.24 \pm 0.30 \mathrm{mg} / \mathrm{mL}$. The data are not shown.

3.1.6. Peroxynitrite Scavenging Activity. Caesalpinia crista extract did not show any noteworthy result in scavenging peroxynitrite radical, in comparison to the standard gallic acid $\left(\mathrm{IC}_{50}=876.24 \pm 56.96 \mu \mathrm{g} / \mathrm{mL}\right)$. So, the results and the figures are not provided.

3.1.7. Inhibition of RNO Bleaching. Caesalpinia crista extract was an effective scavenger of singlet oxygen (Figure 5) and this activity was comparable to that of lipoic acid. The $\mathrm{IC}_{50}$ value (Table 1) of the test sample was found to be $61.13 \pm$ $3.24 \mu \mathrm{g} / \mathrm{mL}$, whereas the $\mathrm{IC}_{50}$ value of lipoic acid was found to be $49.48 \pm 8.56 \mu \mathrm{g} / \mathrm{mL}$. At $100 \mu \mathrm{g} / \mathrm{mL}$, the percentage of 
TABLE 1: Reactive oxygen species scavenging and iron chelating activity ( $\mathrm{IC}_{50}$ values) of C. crista and reference compounds.

\begin{tabular}{llr}
\hline Activity & Extract/reference & IC $_{50}{ }^{a}$ \\
\hline Hydroxyl radical $\left(\mathrm{OH}^{*}\right)$ scavenging & Caesalpinia crista & $0.44 \pm 0.1(6)$ \\
& Mannitol & $0.85 \pm 0.02(6)^{* * *}$ \\
Superoxide anion $\left(\mathrm{O}_{2}{ }^{-}{ }^{-}\right)$scavenging & Caesalpinia crista & $24.9 \pm 0.98(6)$ \\
& Quercetin & $47.38 \pm 0.68(6)^{* * *}$ \\
Nitric oxide radical $(\mathrm{NO})$ scavenging & Caesalpinia crista & $33.72 \pm 0.85(6)$ \\
& Curcumin & $97.12 \pm 3.09(6)^{* * *}$ \\
Singlet oxygen $\left({ }^{1} \mathrm{O}_{2}\right)$ scavenging & Caesalpinia crista & $61.13 \pm 3.24(6)$ \\
& Lipoic acid & $49.48 \pm 8.56(6)^{* *}$ \\
Hypochlorous acid $(\mathrm{HOCl})$ scavenging & Caesalpinia crista & $170.51 \pm 4.68(6)$ \\
Iron chelating activity & Ascorbic acid & $198.42 \pm 10.71(6)^{* *}$ \\
& Caesalpinia crista & $279.85 \pm 4.72(6)$ \\
\hline
\end{tabular}

${ }^{\mathrm{a}}$ Unit of $\mathrm{IC}_{50}$ values of all activities is $\mu \mathrm{g} / \mathrm{mL}$, except $\mathrm{OH}^{\bullet}$ scavenging where unit is $\mathrm{mg} / \mathrm{mL}$. Data are expressed as mean $\pm \mathrm{SD}$. Data in parentheses indicate number of independent assays. EDTA represents ethylenediamine tetraacetic acid.

${ }^{* *} P<.01 ;{ }^{* * *} P<.001$ versus $C$. crista.

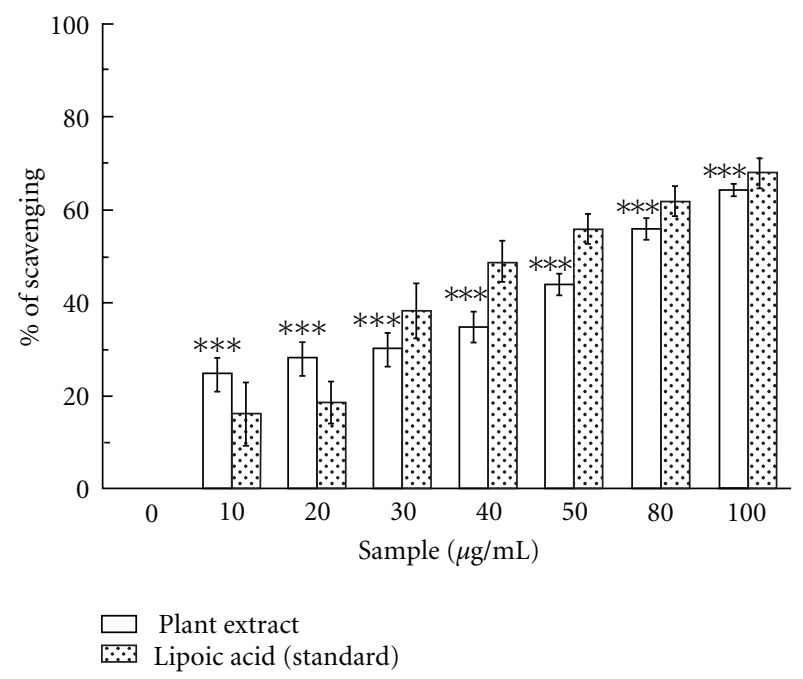

FIgURE 5: Inhibition of RNO bleaching. Effects of C. crista leaf extract and standard lipoic acid on the scavenging of singlet oxygen. $* * * P<.001$ versus $0 \mu \mathrm{g} / \mathrm{mL}$.

scavenging of the plant extract was $64.18 \%$ whereas that of lipoic acid was $67.7 \%$. subsubsectionHypochlorous Acid Scavenging Activity

Figure 6 shows the dose-dependent hypochlorous acid scavenging activity of $C$. crista extract compared to that of ascorbic acid. The obtained results indicate that the extract scavenged hypochlorous acid more efficiently $\left(\mathrm{IC}_{50}\right.$ $=170.51 \pm 4.68 \mu \mathrm{g} / \mathrm{mL})$ than ascorbic acid $\left(\mathrm{IC}_{50}=198.42\right.$ $\pm 10.71 \mu \mathrm{g} / \mathrm{mL}$ ) (Table 1). At $200 \mu \mathrm{g} / \mathrm{mL}$, the percentage of scavenging of the plant extract was $52.64 \%$, whereas that of ascorbic acid was $54.91 \%$.

3.1.8. Inhibition of $\mathrm{Fe}^{2+}$-Ferrozine Formation. Ferrozine makes a violet colored complex with $\mathrm{Fe}^{2+}$ ion. The complex formation is interrupted in presence of chelating agent and as a result the violet color of the complex is decreased. The

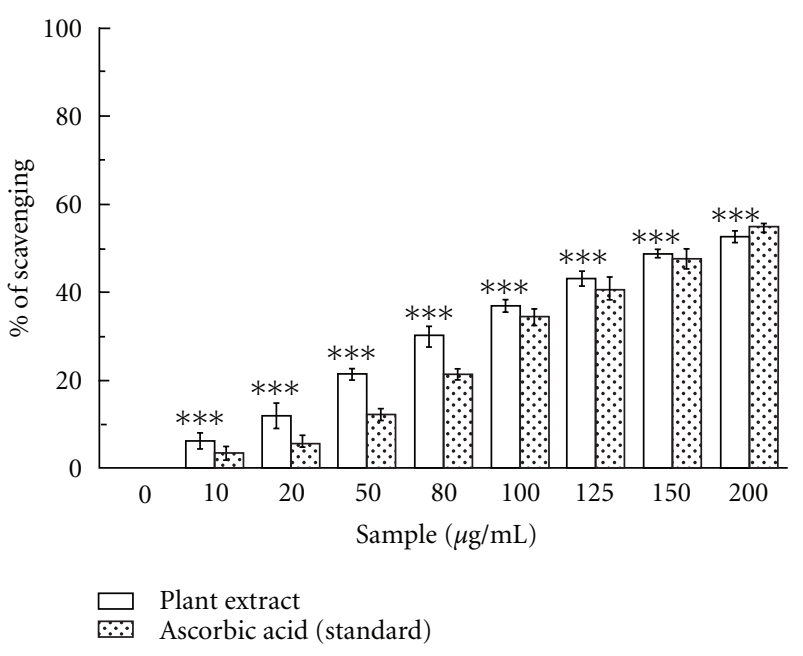

FIGURE 6: Hypochlorous acid scavenging activity. Hypochlorous acid scavenging activities of $C$. crista leaf extract and standard ascorbic acid. ${ }^{* * *} P<.001$ versus $0 \mu \mathrm{g} / \mathrm{mL}$.

results (Figures $7(\mathrm{a})$ and $7(\mathrm{~b})$ ) demonstrated that the formation of ferrozine- $\mathrm{Fe}^{2+}$ complex is inhibited in the presence of test and reference compound. The $\mathrm{IC}_{50}$ values (Table 1) of the plant extract and EDTA were $279.85 \pm 4.72 \mu \mathrm{g} / \mathrm{mL}$ and $1.27 \pm 0.05 \mu \mathrm{g} / \mathrm{mL}$, respectively. At $300 \mu \mathrm{g} / \mathrm{mL}$, the percentage of inhibition of complex formation by the plant extract was $43.33 \%$, whereas at $45 \mu \mathrm{g} / \mathrm{mL}$ that of EDTA was $99.5 \%$.

3.1.9. Total Reduction Capability. As illustrated in Figure 8, from $\mathrm{Fe}^{3+}$ to $\mathrm{Fe}^{2+}$ transformation in the presence of $C$. crista extract and reference ascorbic acid was performed to measure the reductive capability. Although the activity of ascorbic acid was better than the sample with absorbance values of 0.47 and 0.167 for the reference and sample, respectively, still the sample showed somewhat moderate reducing capability. 


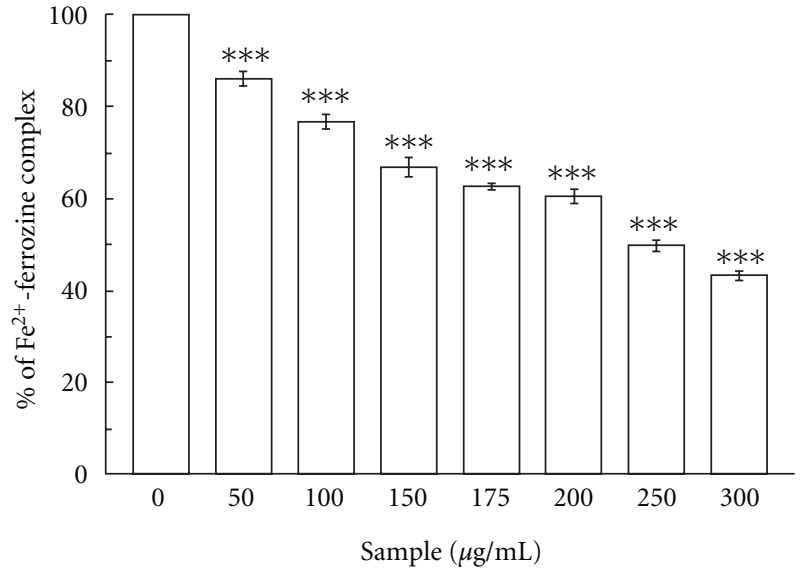

(a)

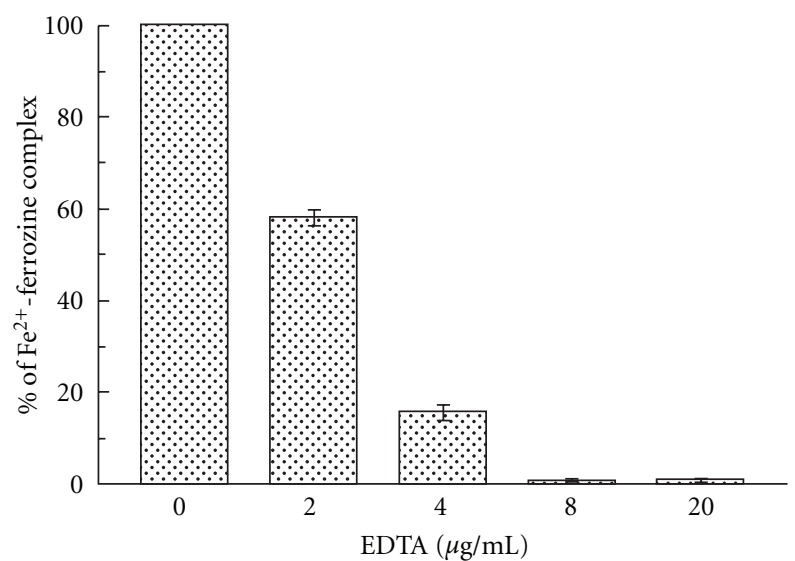

EDTA

(b)

Figure 7: Inhibition of $\mathrm{Fe}^{2+}$-ferrozine formation. Effects of (a) C. crista leaf extract and (b) standard EDTA on ferrozine- $-\mathrm{Fe}^{2+}$ complex formation. The data expressed as percentage inhibition of chromogen formation. ${ }^{* * *} P<.001$ versus $0 \mu \mathrm{g} / \mathrm{mL}$.

3.1.10. Amount of Total Phenolic Content. Phenolic compounds may be directly related to the antioxidative action. The total phenolic content was $50.23 \pm 0.003 \mathrm{mg} / \mathrm{mL}$ gallic acid equivalent per 100-mg plant extract.

3.1.11. Amount of Total Flavonoids. Total flavonoid content of the $70 \%$ methanolic extract of C. crista was $106.83 \pm$ $0.0003 \mathrm{mg} / \mathrm{mL}$ quercetin per $100-\mathrm{mg}$ plant extract.

\subsection{In Vivo Antioxidant Assay}

3.2.1. Effect on Enzyme Activity. The oral administration of plant extract to normal mice for 7 days significantly enhanced the activity of SOD in a dose dependent manner. The results are significant $(P<.001$ at the dose of 50 and $100 \mathrm{mg} / \mathrm{kg}$ body weight and $P<.01$ at the dose of $10 \mathrm{mg} / \mathrm{kg}$ body weight) when compared with control (Table 2$)$. The

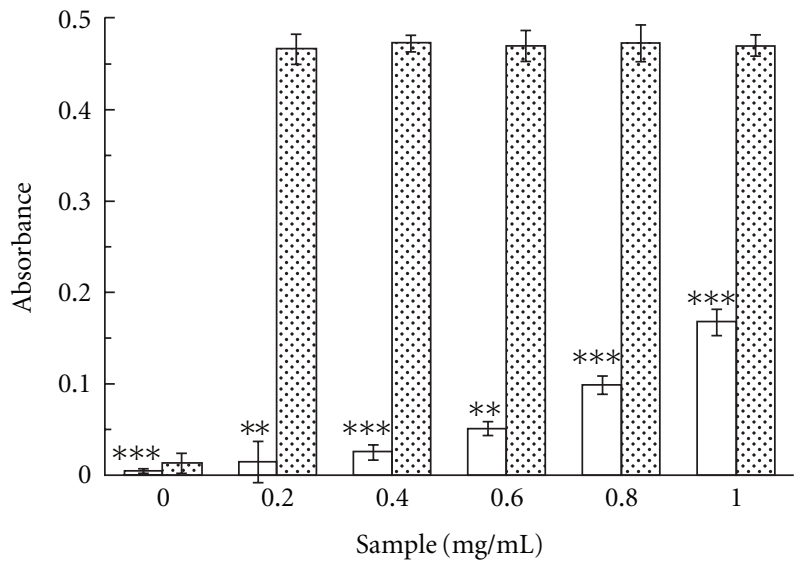

Plant extract
Ascorbic acid (standard)

FIgure 8: Total reduction capability. The reductive ability of $C$. crista leaf extract and standard ascorbic acid. The absorbance $\left(\mathrm{A}_{700}\right)$ was plotted against concentration of sample. ${ }^{* *} P<.01$ and ${ }^{* * *} P<$ .001 versus $0 \mathrm{mg} / \mathrm{mL}$.

treatment induced catalase activity significantly $(P<.05)$ at the dose of 50 and $100 \mathrm{mg} / \mathrm{kg}$ body weight (Table 2). The level of GST was also increased significantly (Table 2) at the dose of 50 and $100 \mathrm{mg} / \mathrm{kg}$ body weight $(P<.05$ and $P<.001$, resp., compared with control). The dose-dependent augment of GSH content (Table 2) was also found to be significant $(P<.05$ at $10 \mathrm{mg} / \mathrm{kg}$ body weight and $P<.001$ at 50 and $100 \mathrm{mg} / \mathrm{kg}$ body weight).

\section{Discussion}

ROS are responsible for the damage of cellular bio-molecules such as proteins, enzymes, nucleic acids, lipids and carbohydrates and may adversely affect immune functions [30]. Antioxidants interrupt the production of ROS and also play a key role to inactivate them. Although, all human cells protect themselves against oxidative damage by some antioxidant mechanism, these sometimes are not sufficient to prevent the ROS damage totally. Different kind of plant materials have already been reported as natural antioxidants [31, 32]. Recently, we have also shown the antioxidant and ROS scavenging activity of Spondias pinnata bark [33].

In Ayurveda, the seeds, root-bark and the leaves of $C$. crista are used for medicinal purpose. Externally, the paste of leaves gives great relief from the pain and edema. Internally, it is the best panacea of abdominal pain, diarrhea, dysentery and colitis. The present results of the study demonstrate that $70 \%$ methanolic extract of C. crista has potent antioxidant activity and ROS scavenging activity as well as iron chelating property.

The reaction between ABTS and potassium persulfate results in the production of a blue colored chromophore, ABTS $^{\bullet+}$. After addition of the plant extract this pre-formed radical cation was converted to ABTS in a dose dependant 
TABLE 2: Effect of the methanolic extract of C. crista leaves on the activities of antioxidant enzymes and reduced glutathione content in liver of normal mice.

\begin{tabular}{lcccc}
\hline Tested parameter & Group I & Group II & Group III & Group IV \\
\hline SOD (U/mg protein) & $1.22 \pm 0.54$ & $2.61 \pm 0.2^{* *}$ & $2.96 \pm 0.19^{* * *}$ & $3.37 \pm 0.2^{* * *}$ \\
CAT (U/mg protein) & $0.9 \pm 0.72$ & $1.19 \pm 0.09$ & $1.5 \pm 0.37^{*}$ & $1.66 \pm 0.43^{*}$ \\
GST (U/mg protein) & $0.22 \pm 0.05$ & $0.31 \pm 0.1$ & $0.31 \pm 0.08^{*}$ & $0.42 \pm 0.08^{* * *}$ \\
GSH $(\mu \mathrm{g} / \mathrm{mg}$ protein) & $1.16 \pm 0.04$ & $1.43 \pm 0.12^{*}$ & $1.78 \pm 0.08^{* * *}$ & $2.1 \pm 0.09^{* * *}$ \\
\hline
\end{tabular}

Group I: control group; Group II: mice treated orally with the extract in a dose of $10 \mathrm{mg} / \mathrm{kg}$ body weight; Group III: mice treated orally with the extract in a dose of $50 \mathrm{mg} / \mathrm{kg}$ body weight; Group IV: mice treated orally with the extract in a dose of $100 \mathrm{mg} / \mathrm{kg}$ body weight. Results are expressed as mean \pm SD for six mice in each group.

${ }^{*} P<.05,{ }^{*} P<.01,{ }^{* * *} P<.001$ compared with control.

manner. The result is compared with trolox and the TEAC value demonstrates the extract as a potent antioxidant.

Hydroxyl radical is one of the ROS formed in biological systems, causing DNA strand breakage, which brings about carcinogenesis, mutagenesis and cytotoxicity [34]. $\mathrm{Fe}^{3+}-$ EDTA premixture is incubated with ascorbic acid and $\mathrm{H}_{2} \mathrm{O}_{2}$ at $\mathrm{pH}$ 7.4. Thus, hydroxyl radicals are formed, which cause 2-deoxy-2-ribose damage and generate malondialdehyde (MDA) like product. This compound forms a pink chromogen upon heating with TBA at low $\mathrm{pH}$ [35]. Addition of the C. crista extract to the reaction mixture removes hydroxyl radicals and prevents further damage. The observed $\mathrm{IC}_{50}$ value indicates that the plant extract is a better hydroxyl radical scavenger than standard mannitol.

Superoxide anion is also implicated as harmful ROS. It has detrimental effect on the cellular components in a biological system [36]. It indirectly initiates lipid oxidation by generating singlet oxygen. The dose dependent increase in the scavenging activity of the plant extract and the standard quercetin for superoxide radical (Figure 3 ) suggest that the former is more potent scavenger than the latter.

The production of nitric oxide radical at a sustained level results in direct tissue toxicity and contribute to the vascular collapse associated with septic shock, whereas chronic expression of nitric oxide radical is associated with various carcinomas and inflammatory conditions including juvenile diabetes, multiple sclerosis, arthritis and ulcerative colitis [37]. The reaction of $\mathrm{NO}$ with superoxide radical generates highly reactive peroxynitrite anion $\left(\mathrm{ONOO}^{-}\right)$ which is highly toxic for living cell [38]. The nitric oxide generated from sodium nitroprusside reacts with oxygen to form nitrite. The extract directly competes with oxygen to react with nitric oxide, thus inhibiting nitrite formation. The present study proved that the nitric oxide scavenging activity of the studied extract is better than the standard curcumin.

Another ROS, singlet oxygen which is a high energy form of oxygen, is generated in the skin upon UV-irradiation. Singlet oxygen induces hyperoxidation, oxygen cytotxicity and decreases the antioxidative activity [39]. The present study indicates that the C. crista extract has restrained scavenging activity for singlet oxygen but is not as efficient as the standard lipoic acid.

At the sites of inflammation, the oxidation of $\mathrm{Cl}^{-}$ions by the neutrophil enzyme myeloperoxidase results in the production of another harmful ROS, hypochlorous acid
[40]. HOCl has the ability to inactivate the antioxidant enzyme, catalase through break down of heme-prosthetic group. The inhibition of catalase inactivation in the presence of the extract signifies its $\mathrm{HOCl}$ scavenging activity and from the results obtained, it is anticipated that C. crista is the more efficient scavenger than standard ascorbic acid.

The two oxidation states of iron, $\mathrm{Fe}^{2+}$ and $\mathrm{Fe}^{3+}$ donate or accept electrons through redox reactions that are significant for biological reactions, but they also may be harmful to cells [41]. In excess, iron helps superoxide anion $\left(\mathrm{O}^{\bullet 2-}\right)$ and hydrogen peroxide to convert into the extremely reactive hydroxyl radical $\left(\mathrm{OH}^{\bullet}\right)$ (Haber-Weiss reaction) that cause severe injury to membranes, proteins and DNA [2]. It decomposes lipid hydro-peroxides into peroxyl and alkoxyl radicals responsible for the chain reaction of lipid peroxidation [42]. The results from Figure 7 and Table 1 suggest that the decrease in the concentration dependent color formation with ferrozine in presence of extract indicating its iron chelating property. However, compared to standard EDTA, it shows less activity.

The reducing capacity of a compound may serve as a significant indicator of its potential antioxidant activity. As shown in Figure 8, it may be observed that the plant extract has some reducing capacity, thus justifying its antioxidant capacity.

It is also found that C. crista plant extract shows significant amount of flavonoid and phenolic content. Flavonoids show their antioxidative action through scavenging or chelating process [43]. Phenolic content is also very important plant constituent because of their scavenging ability due to their hydroxyl groups [44]. Both of these compounds have good antioxidant potential and their effects on human nutrition and health are significant.

It has been reported that body's antioxidant defense system consisting of the activity of SOD, CAT, GST and GSH [45]. SOD catalyzes the breakdown of endogenous cytotoxic superoxide radicals to $\mathrm{H}_{2} \mathrm{O}_{2}$ which is further degraded by CAT. Thus, they play a crucial role in maintaining the physiological levels of $\mathrm{O}_{2}$ and $\mathrm{H}_{2} \mathrm{O}_{2}{ }^{\bullet} \mathrm{GSH}$, in conjunction with GST, has a basic role in cellular defense against deleterious free radicals and other oxidant species [46]. GST catalyzes the conjugation of thiol group of glutathione to electrophilic substrates, and thereby detoxifies endogenous compounds such as peroxidized lipids [47]. The present study supports the antioxidant potency of the plant extract as 


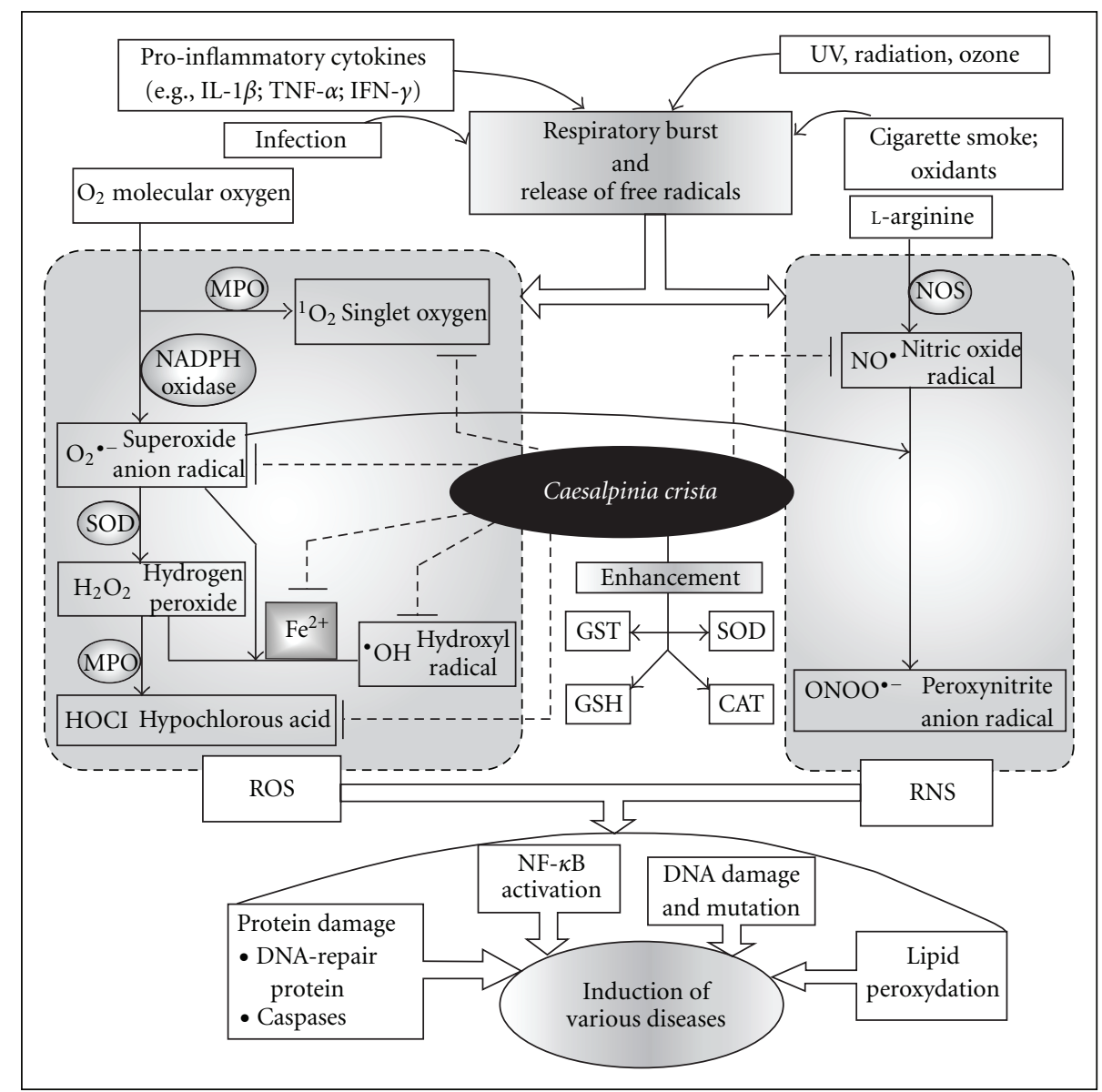

FIGURE 9: Role of C. crista in prevention of diseases caused by free radicals. Generation of ROS and reactive nitrogen species (RNS) is initiated by respiratory burst, which is set off by various physiological and environmental factors. The fabrication of an assortment of ROS and RNS from the molecular $\mathrm{O}_{2}$ and L-arginine, respectively, carried on by different enzymes like MPO (myloperoxidase), NADPH oxidase, SOD (superoxide dismutase) and NOS (nitric oxide synthase) leads to diverse cellular phenomena, namely, damage of DNA-repair proteins and caspases, lipid peroxydation, DNA damage followed by mutation and NF- $\kappa$ B activation. All these phenomena give rise to wide range of diseases. Caesalpinia crista leaf extract inhibits the generations of the free radicals by scavenging both the mother and the daughter products and also by inducing the increase of SOD, CAT, GST and GSH, resulting the obstruction of various disease formation.

evidenced by the increased level of these antioxidant systems in extract treated mice.

\section{Conclusions}

Conclusively, it can be avowed that the $70 \%$ methanolic extract of $C$. crista leaves, which contains high amount of flavonoid and phenolic contents, exhibits high antioxidant and ROS scavenging activity. It also has iron chelating property. Furthermore, evaluation of in vivo antioxidant activity of this extract has also provided interesting results that might be beneficial for the pharmacological use of this plant in clinical trials. In a word, these results signify that this plant extract is an important source of natural antioxidant, which might play a vital role in preventing the progress of various oxidative stresses, in course of enhancing the generation of typical antioxidant enzymes (Figure 9). Thus, these inspiring results provide the impetus to investigate the reason behind the antioxidative property.

\section{Acknowledgments}

The authors would like to thank Mr Ranjit Das and Mr Amartya Sen for assistance. S. Mandal and B. Hazra contributed equally to this work.

\section{References}

[1] A. K. Tiwari, "Imbalance in antioxidant defence and human diseases: multiple approach of natural antioxidants therapy," Current Science, vol. 81, no. 9, pp. 1179-1187, 2001.

[2] E. R. Stadtman, "Protein oxidation and aging," Science, vol. 257, no. 5074, pp. 1220-1224, 1992.

[3] S. R. J. Maxwell, "Prospects for the use of antioxidant therapies," Drugs, vol. 49, no. 3, pp. 345-361, 1995.

[4] S. K. Kalauni, S. Awale, Y. Tezuka, A. H. Banskota, T. Z. Linn, and S. Kadota, "Methyl migrated cassane-type furanoditerpenes of Caesalpinia crista from Myanmar," Chemical and Pharmaceutical Bulletin, vol. 53, no. 10, pp. 1300-1304, 2005. 
[5] S. Cheenpracha, R. Srisuwan, C. Karalai et al., "New diterpenoids from stems and roots of Caesalpinia crista," Tetrahedron, vol. 61, no. 36, pp. 8656-8662, 2005.

[6] E. M. Williamson, Major Herbs of Ayurveda, Elsevier Health Sciences, Edinburgh, UK, 2002.

[7] N. C. Neogi and K. P. Nayak, "Biological investigation of Caesalpinia bonducella Flem," Indian Journal of Pharmacy, vol. 20, pp. 95-100, 1958.

[8] M. L. Dhar, M. M. Dhar, B. N. Dhawan, B. N. Mehrotra, and C. Ray, "Screening of Indian plants for biological activity," Indian Journal of Experimental Biology, vol. 6, no. 4, pp. 232-247, 1968.

[9] V. V. Rao, S. K. Dwivedi, and D. Swarup, "Hypoglycaemic effect of Caesalpinia bonducella in rabbits," Fitoterapia, vol. 65, no. 3, pp. 245-247, 1994.

[10] A. Jabbar, M. A. Zamana, Z. Iqbala, M. Yaseenb, and A. Shamim, "Anthelmintic activity of Chenopodium album (L.) and Caesalpinia crista (L.) against trichostrongylid nematodes of sheep," Journal of Ethnopharmacology, vol. 114, pp. 86-91, 2007.

[11] E. Nathala and S. Dhingra, "Biological effects of Caesalpinia crista seed extracts on Helicoverpa armigera (Lepidoptera: Noctuidae) and its Predator, Coccinella septumpunctata (Coleoptera: Coccinellidae)," Journal of Asia-Pacific Entomology, vol. 9, no. 2, pp. 159-164, 2006.

[12] R. Re, N. Pellegrini, A. Proteggente, A. Pannala, M. Yang, and C. Rice-Evans, "Antioxidant activity applying an improved ABTS radical cation decolorization assay," Free Radical Biology and Medicine, vol. 26, no. 9-10, pp. 1231-1237, 1999.

[13] E. Kunchandy and M. N. A. Rao, "Oxygen radical scavenging activity of curcumin," International Journal of Pharmaceutics, vol. 58, no. 3, pp. 237-240, 1990.

[14] M. Fontana, L. Mosca, and M. A. Rosei, "Interaction of enkephalins with oxyradicals," Biochemical Pharmacology, vol. 61, no. 10, pp. 1253-1257, 2001.

[15] D. C. Garrat, The Quantitative Analysis of Drugs, Chapman and Hall, Tokyo, Japan, 1964.

[16] L. H. Long, P. J. Evans, and B. Halliwell, "Hydrogen peroxide in human urine: implications for antioxidant defense and redox regulation," Biochemical and Biophysical Research Communications, vol. 262, no. 3, pp. 605-609, 1999.

[17] J. S. Beckman, J. Chen, H. Ischiropoulos, and J. P. Crow, "Oxidative chemistry of peroxynitrite," Methods in Enzymology, vol. 233, pp. 229-240, 1994.

[18] F. Bailly, V. Zoete, J. Vamecq, J. P. Catteu, and J. L. Bernier, "Antioxidant actions of ovothiol-derived 4mercaptoimidazoles: glutathione peroxidase activity and protection against peroxynitrite-induced damage," FEBS Letters, vol. 486, pp. 19-22, 2000.

[19] J. Pedraza-Chaverrí, D. Barrera, P. D. Maldonado et al., "Sallylmercaptocysteine scavenges hydroxyl radical and singlet oxygen in vitro and attenuates gentamicin-induced oxidative and nitrosative stress and renal damage in vivo," BMC Clinical Pharmacology, vol. 4, article 5, 2004.

[20] O. I. Aruoma and B. Halliwell, "Action of hypochlorous acid on the antioxidant protective enzymes superoxide dismutase, catalase and glutathione peroxidase," Biochemical Journal, vol. 248, no. 3, pp. 973-976, 1987.

[21] J. F. Haro-Vicente, C. Martínez-Graciá, and G. Ros, “Optimisation of in vitro measurement of available iron from different fortificants in citric fruit juices," Food Chemistry, vol. 98, no. 4, pp. 639-648, 2006.
[22] M. Oyaizu, "Studies on products of browning reactions: antioxidant activities of products of browning reaction prepared from glucose amine," Japanese Journal of Nutrition, vol. 44, pp. 307-315, 1986.

[23] V. L. Singleton and J. A. Rossi, "Colorimetry of total phenolics with phosphomolybdic-phosphotungstic acid reagents," American Journal of Enology and Viticulture, vol. 16, pp. 144158, 1965.

[24] J. Jia, M. Tang, and J. Wu, "The determination of flavonoid content in mulberry and their scavenging effects on superoxide radicals," Food Chemistry, vol. 64, pp. 555-559, 1999.

[25] O. H. Lowry, M. J. Roesborough, A. L. Farr, and R. J. Randall, "Protein measurement with Folin-Phenol reagent," Journal of Biological Chemistry, vol. 193, pp. 265-275, 1951.

[26] P. Kakkar, B. Das, and P. N. Viswanathan, "A modified spectrophotometric assay of superoxide dismutase," Indian Journal of Biochemistry and Biophysics, vol. 21, no. 2, pp. 130132, 1984.

[27] J. Bonaventura, W. A. Schroeder, and S. Fang, "Human erythrocyte catalase: an improved method of isolation and a reevaluation of reported properties," Archives of Biochemistry and Biophysics, vol. 150, no. 2, pp. 606-617, 1972.

[28] W. H. Habig, M. J. Pabst, and W. B. Jakoby, "Glutathione $S$ transferases. The first enzymatic step in mercapturic acid formation," Journal of Biological Chemistry, vol. 249, no. 22, pp. 7130-7139, 1974.

[29] G. L. Ellman, "Tissue sulfhydryl group," Archives of Biochemistry and Biophysics, vol. 82, pp. 70-77, 1959.

[30] J. Nilsson, R. Stegmark, and B. Åkesson, "Total antioxidant capacity in different pea (Pisum sativum) varieties after blanching and freezing," Food Chemistry, vol. 86, no. 4, pp. 501-507, 2004.

[31] P. Ljubuncic, S. Dakwar, I. Portnaya, U. Cogan, H. Azaizeh, and A. Bomzon, "Aqueous extracts of Teucrium polium possess remarkable antioxidant activity in vitro," EvidenceBased Complementary and Alternative Medicine, vol. 3, no. 3, pp. 329-338, 2006.

[32] H. Liao, L. K. Banbury, and D. N. Leach, "Antioxidant activity of 45 Chinese herbs and the relationship with their TCM characteristics," Evidence-Based Complementary and Alternative Medicine, vol. 5, no. 4, pp. 429-434, 2008.

[33] B. Hazra, S. Biswas, and N. Mandal, "Antioxidant and free radical scavenging antivity of Spondias pinnata," BMC Complementary and Alternative Medicine, vol. 8, p. 63, 2008.

[34] L. Packer and A. S. H Ong, Biological Oxidants and Antioxidants:Molecular Mechanisms and Health Effects, AOCSPress, Champaign, Ill, USA, 1997.

[35] O. I. Aruoma, B. Halliwell, and M. Dizdaroglu, "Iron iondependent modification of bases in DNA by the superoxide radical-generating system hypoxanthine/xanthine oxidase," Journal of Biological Chemistry, vol. 264, no. 22, pp. 1302413028, 1989.

[36] B. Halliwell, J. M. C. Gutteridge, and O. I. Aruoma, "The deoxyribose method: a simple 'test-tube' assay for determination of rate constants for reactions of hydroxyl radicals," Analytical Biochemistry, vol. 165, no. 1, pp. 215-219, 1987.

[37] T. Okuda, Y. Kimura, T. Yoshida, T. Hatamo, H. Okuda, and S. Arichi, "Studies on the activities of tannins and related compounds from medicinal plants and drugs. I. Inhibitory effects on lipid peroxidation in mitochondria and microsomes of liver," Chemical \& Pharmaceutical Bulletin, vol. 31, pp. 1625-1631, 1983. 
[38] B. S. Tylor, Y. M. Kion, Q. I. Wang, R. A. Sharpio, T. R. Billiar, and D. A. Geller, "Nitric oxide down regulates hepatocyteinducible nitric oxide synthase gene expression," Archives of Surgery, vol. 132, pp. 1177-1183, 1997.

[39] I. E. Kochevar and R. W. Redmond, "Photosensitized production of singlet oxygen," Methods in Enzymology, vol. 319, pp. 20-28, 2000.

[40] O. I. Aruoma, B. Halliwell, B. M. Hoey, and J. Butler, "The antioxidant action of $\mathrm{N}$-acetylcysteine: its reaction with hydrogen peroxide, hydroxyl radical, superoxide, and hypochlorous acid," Free Radical Biology \& Medicine, vol. 6, pp. 593-597, 1989.

[41] Y. Yamaji, Y. Nakazato, N. Oshima, M. Hayashi, and T. Saruta, "Oxidative stress induced by iron released from transferrin in low $\mathrm{pH}$ peritoneal dialysis solution," Nephrology Dialysis Transplantation, vol. 19, no. 10, pp. 2592-2597, 2004.

[42] L.-W. Chang, W.-J. Yen, S. C. Huang, and P.-D. Duh, "Antioxidant activity of sesame coat," Food Chemistry, vol. 78, no. 3, pp. 347-354, 2002.

[43] N. C. Cook and S. Samman, "Flavonoids-chemistry, metabolism, cardioprotective effects, and dietary sources," Journal of Nutritional Biochemistry, vol. 7, no. 2, pp. 66-76, 1996.

[44] A. T. Diplock, "Will the good fairies please prove to us that vitamin E lessens human degenerative disease?" Free Radical Research, vol. 27, pp. 511-532, 1997.

[45] U. Bandyopadhyay, D. Das, and R. K. Banerjee, "Reactive oxygen species: oxidative damage and pathogenesis," Current Science, vol. 77, no. 5, pp. 658-666, 1999.

[46] S. Arivazhagan, S. Balasenthil, and S. Nagini, "Garlic and neem leaf extracts enhance hepatic glutathione and glutathione dependent enzymes during N-methyl-N'-nitro-Nnitrosoguanidine (MNNG)-induced gastric carcinogenesis in rats," Phytotherapy Research, vol. 14, no. 4, pp. 291-293, 2000.

[47] M. J. Leaver and S. G. George, "A piscine glutathione-Stransferase which efficiently conjugates the end products of lipid peroxidation," Marine Environmental Research, vol. 46, no. 1-5, pp. 71-74, 1998. 


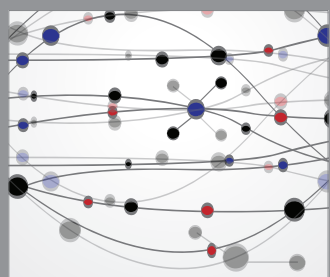

The Scientific World Journal
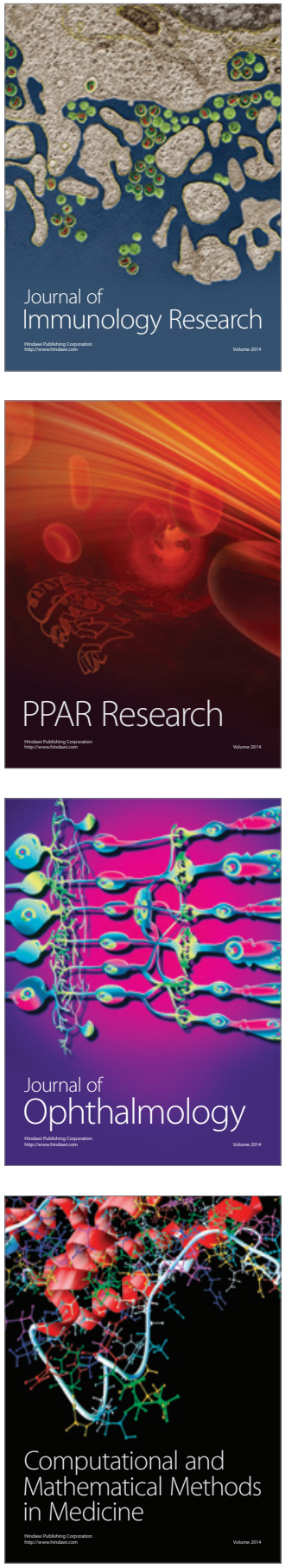

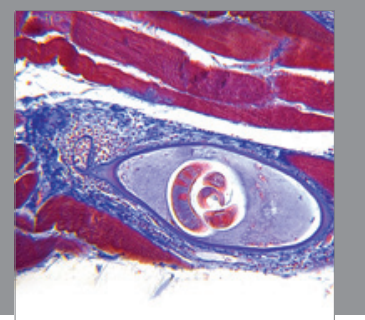

Gastroenterology

Research and Practice
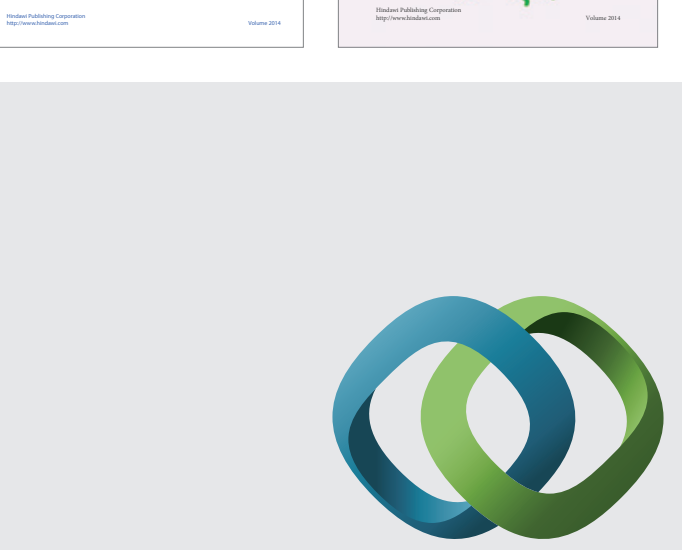

\section{Hindawi}

Submit your manuscripts at

http://www.hindawi.com
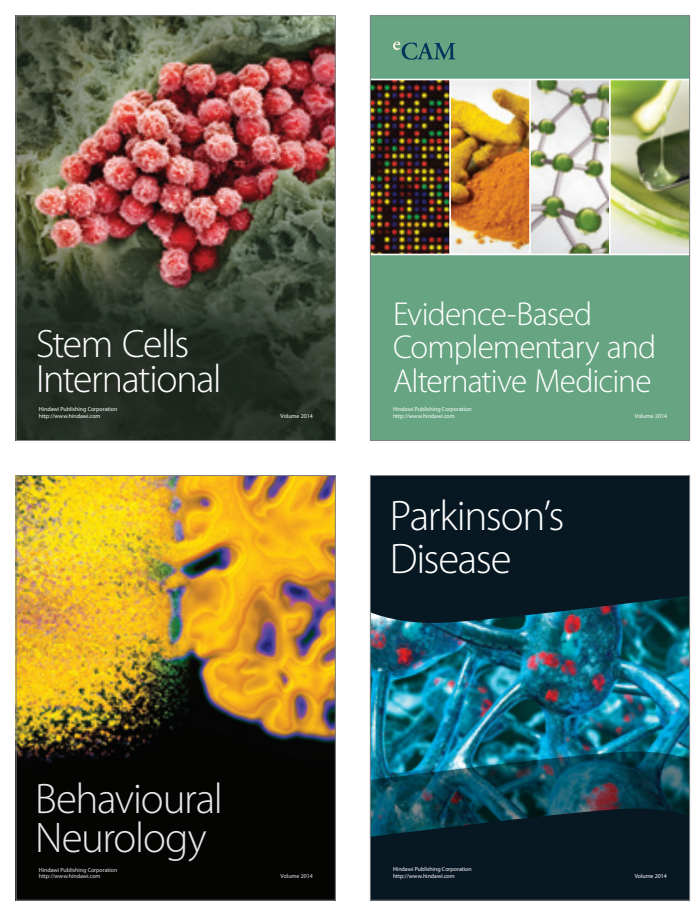

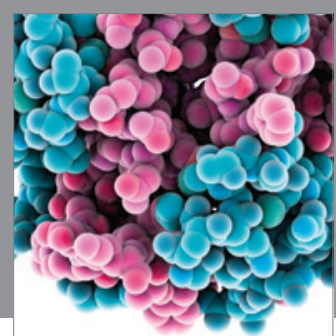

Journal of
Diabetes Research

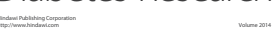

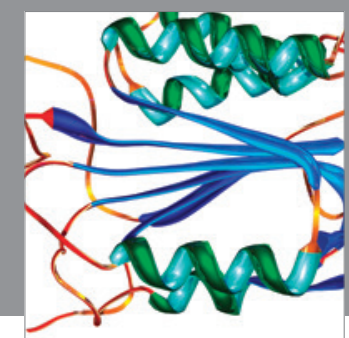

Disease Markers
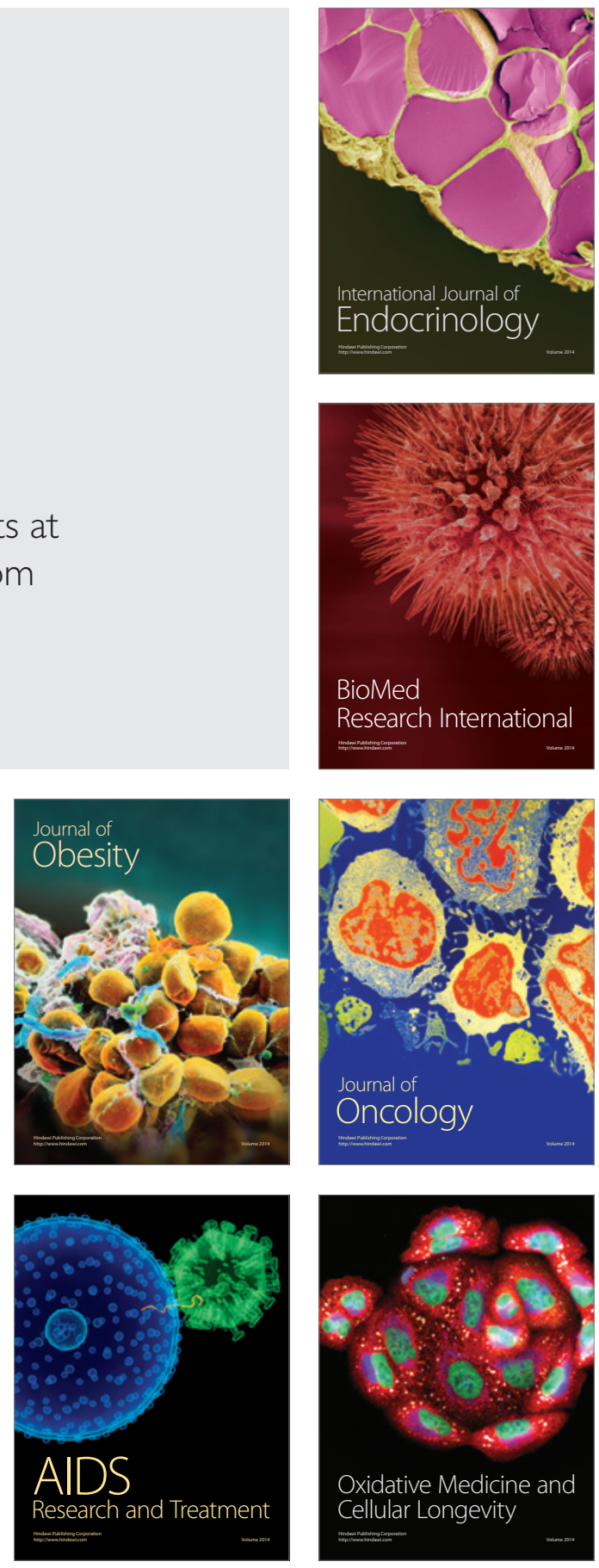